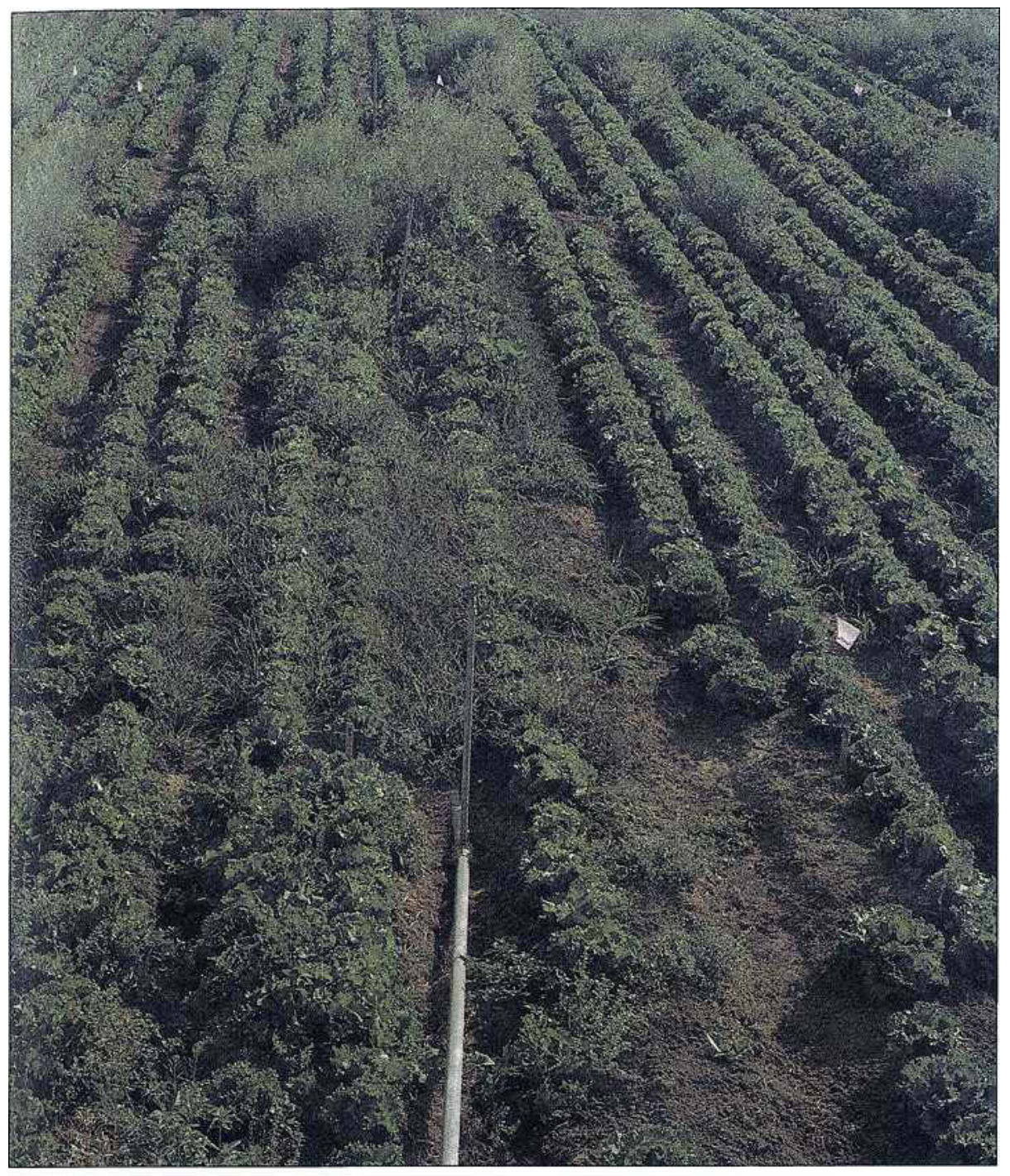

\title{
Low-input management of weeds in vegetable fields
}

\author{
W. Thomas Lanini $\square \quad$ Michelle Le Strange
}

\section{Applying less herbicide to a veg- etable crop can increase weed populations and decrease yields. Field trials showed that for some crops, one timely hand weeding could augment lower-rate applica- tions of pre-emergence herbicides to give crop yields equal to or ex- ceeding those obtained with full- season hand weeding or full-rate herbicide treatments.}

Many vegetable growers control weed problems through a combination of cultivation, hand hoeing, and herbicide treatments. Each of these methods controls weeds for a given time, after which growers must decide whether repeat measures are warranted. Guidelines telling how long weeds must be excluded from particular vegetable crops for optimum crop yields and quality or how to prevent excessive weed seed production may reduce unnecessary weed control measures.

When using herbicides, vegetable growers often apply the highest label-approved rate. They see that by reducing the herbicide rate, they could increase the number of weed species that would escape control. Advantages to applying reduced rates are lower chemical costs, less risk of environmental contamination, and less risk of herbicide carryover into the next crop. Many growers hand hoe to thin the crop stand or to remove
Lettuce and weeds compete, with various results, in these comparison plots at the West Side Agricultural Field Station.

weeds missed by the herbicide treatment. Decreasing herbicide application rates and then removing the surviving weeds with a hoe maybe practical if cropyields and quality are preserved.

\section{Field trials}

We conducted our studies at the University of California West Side Field Station at Five Points and at the Davis Research Farm. Our investigations looked into bell pepper, cauliflower, cucumber, and lettuce yields with various weed-free periods. Crops were kept weed-free by hand hoeing for $0,2,4,6,8$, or 10 weeks after crop emergence, or for the full season. After the weed-free period, we allowed weeds to grow freely.

Weplanted cucumbers (variety 'Perfecto Verde 14') and bell peppers (var. 'Jupiter') in April or early May each year, and cauliflower (var. 'White Cloud') in August. Lettuce was planted in August (var. Fame - Empire type') as a fall crop or in February (var. 'Coolguard') as a spring crop. All crops were direct seeded. Weed seeds were broadcast and incorporated into the soil before vegetable planting. A mixture of summer annuals including redroot pigweed, barnyardgrass, black nightshade, common purslane, and lambsquarters were used in all bell pepper and cucumber trials. In the lettuce and cauliflower trials, we sowed annualbluegrass, chickweed, London rocket, and shepherdspurse seeds.

The herbicides were applied at the most common rates for the crop and at one-half or less of those standard treatments. We also combined the use of a single hand hoeing with a half-rate herbicide application. Standard pre-emergence herbicide treatments included Alanap (naptalam) plus Prefar (bensulide), each at 4 pounds active ingredient per acre ( $4 \mathrm{lb}$ ai/ac) for cucumbers; Devrinol (napropamide) at $2 \mathrm{lb}$ ai / ac for bell peppers; Dacthal (DCPA) at $10 \mathrm{lb}$ ai/ac for cauliflower; and Kerb (pronamide) at $2 \mathrm{lb}$ ai/ac for lettuce.

We measured crop yields at harvest. Cucumbers were picked six times at 5-day intervals, and bell peppers were picked twice, 28 days apart. We picked lettuce and cauliflower once each. The weed cover was visually determined from two randomly placed $0.5 \mathrm{~m}^{-2}$ quadrats from each plot at harvest.

\section{Results and discussion}

Bell pepper. Weed-free periods of 6 weeks or less after crop emergence reduced bell pepper yields by $40 \%$ or more (fig. 1). Bell pepper plants grew slowly, requiring at least 8 weeks without weed competition to reach their full yield potential. Vegetative growth and fruiting were severely limited by weed 


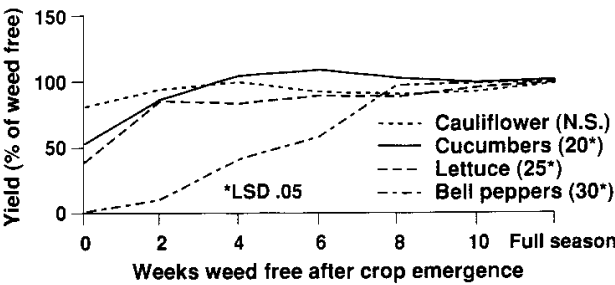

Fig. 1. Vegetable yields for four crops, relative to the number of weeks following crop emergence that the crops are weed free.

competition. Once the canopy development was virtually complete, bell peppers were able to flower and set fruit; after this point weed competition did not influence yields.

Devrinol treatment at $2 \mathrm{lb}$ ai/ac did not control weeds effectively through the season, when compared to weed-free plots (table 1). Observations indicated that weed contro from Devrinol lasted 4 to 6 weeks. The short residual activity results in part from the frequent sprinkler irrigations applied to the beds to prevent the soil from crusting during the 3 weeks bell peppers take to emerge.

Thus, bell peppers had at most three weeks to grow without significant weed competition. Weeds germinating after this period were quick to outcompete the slowgrowing bell peppers. Addition of a hand hoeing at 5 or 7 weeks did not significantly improve yields as compared to those with the Devrinol application alone. Delaying hand hoeing until the fifth or seventh week permitted some weeds that had survived the Devrinol treatment, such as black nightshade, to attain a relatively large size. Competition from the weeds reduced bell pepper growth, and the act of removing them caused some root or shoot disturbance to most bell pepper plants.

Cucumbers. Unlike bell peppers, cucumbers competed well with weeds, so keeping weeds out for 3 weeks after crop emergence resulted in yields within $10 \%$ of those obtained from full-season hand hoe treatments(fig. 1). Cucumbers grew rapidly, their leaves climbing over emerged weeds to shade them and any bare soil. Once cover wasestablished, the weeds did notgerminate or compete effectively to influence crop yields.

Lack of weed control resulted in only a $45 \%$ reduction in cucumber yields, but the weeds made harvesting more difficult. Controlling weeds for 6 weeks with no additional hand hoeing produced the highest yields. Hand hoeing 8 weeks or more after crop emergence appeared to disturb cucumber roots and vine shoots, reducing yields somewhat. In a comparison of lateseason (6 weeks or more after cucumber emergence) removal of broadleaf versus grass weeds, removing grasses resulted in over twice the yield reduction ( 3 to $15 \%$ ) of removing broadleaf weeds ( 1 to $5 \%$ ). $\mathrm{Cu}$ -
TABLE 1. Bell pepper yield and weed cover at harvest as influenced by Devrinol applications hand hoeing, or combinations of the two

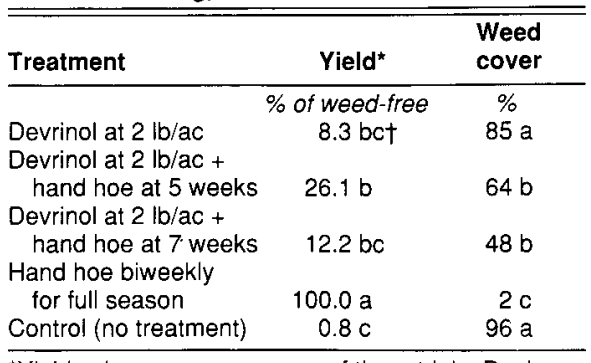

"Yield values are an average of three trials: Davis 1988 and 1989, and Five Points 1989. Yields of $100 \%=10,300 \mathrm{lb} / \mathrm{ac}$.

†Values followed by the same letter are not significantly different $(P>.05)$.

\begin{tabular}{|c|c|c|}
\hline reatment & Yield $^{\star}$ & $\begin{array}{l}\text { Weed } \\
\text { cover }\end{array}$ \\
\hline & $\%$ of weed-free & $\%$ \\
\hline $\begin{array}{l}\text { lanap + Prefar, } \\
\text { each at } 4 \mathrm{lb} / \mathrm{ac} \\
\text { lanap + Prefar, }\end{array}$ & $82 \mathrm{ab} \dagger$ & $39 \mathrm{bc}$ \\
\hline $\begin{array}{l}\text { each at } 2 \mathrm{lb} / \mathrm{ac} \\
\text { lanap + Prefar, } \\
\text { each at } 2 \mathrm{lb} / \mathrm{ac},+\end{array}$ & $73 b$ & $50 \mathrm{~b}$ \\
\hline $\begin{array}{l}\text { hand hoe at } 3 \text { weeks } \\
\text { land hoe biweekly }\end{array}$ & 99 a & $24 \mathrm{~cd}$ \\
\hline $\begin{array}{l}\text { for full season } \\
\text { ontrol (no treatment) }\end{array}$ & $\begin{array}{r}100 \mathrm{a} \\
50 \mathrm{c}\end{array}$ & $\begin{array}{l}12 d \\
84 a\end{array}$ \\
\hline
\end{tabular}

"Yield values are an average of four trials: Davis 1988 and 1989 and Five Points 1988 and 1989. Yields of $100 \%=37,300 \mathrm{lb} / \mathrm{ac}$.

†Values followed by the same letter are not significantly different $(P>.05)$.

TABLE 3. Lettuce yield and weed cover at harvest as influenced by Kerb applications, hand hoeing, or combinations of the two

\begin{tabular}{lcc}
\hline Treatment & Yield $^{*}$ & $\begin{array}{c}\text { Weed } \\
\text { cover }\end{array}$ \\
\hline $\begin{array}{c}\text { Kerb at 2 lb/ac } \\
\text { Kerb at 1 lb/ac }\end{array}$ & 74 & $\%$ \\
$\begin{array}{l}\text { Kerb at } 1 \mathrm{lb} / \mathrm{ac}+ \\
\text { hand hoe at } 4 \text { weeks }\end{array}$ & 76 & $\begin{array}{c}74 \mathrm{ab} \dagger \\
75 \mathrm{a}\end{array}$ \\
$\begin{array}{l}\text { Kerb at } 1 \mathrm{lb} / \mathrm{ac}+ \\
\text { hand hoe at } 6 \text { weeks }\end{array}$ & 110 & $60 \mathrm{ab}$ \\
$\begin{array}{l}\text { Hand hoe biweekly } \\
\text { for full season }\end{array}$ & 100 & $24 \mathrm{bc}$ \\
\hline
\end{tabular}

*Yield values are from a single trial at Davis in 1989 Yields of $100 \%=21,200 \mathrm{lb} / \mathrm{ac}$. Weedy control plots yielded no lettuce and had $92 \%$ weed cover. †Values followed by the same letter are not significantly different $(P>.05)$.

TABLE 4. Cauliflower yield and weed cover at harvest as influenced by Dacthal applications or hand hoeing

\begin{tabular}{lcc}
\hline \hline Treatment & Yield $^{*}$ & $\begin{array}{l}\text { Weed } \\
\text { cover }\end{array}$ \\
\hline & $\%$ of weed-free & $\%$ \\
Dacthal at 10 lb/ac & 79 & $19 \mathrm{b \dagger}$ \\
Dacthal at $6 \mathrm{lb} / \mathrm{ac}$ & 98 & $34 \mathrm{~b}$ \\
Dacthal at $4 \mathrm{lb} / \mathrm{ac}$ & 86 & $23 \mathrm{~b}$ \\
Hand hoe biweekly & & $0 \mathrm{C}$ \\
$\quad$ for full season & 100 & $92 \mathrm{a}$ \\
Control (no treatment) & 89 & \\
\hline
\end{tabular}

"Yield values are from a single trial at Five Points in 1988. Yields of $100 \%=43,300 \mathrm{lb} / \mathrm{ac}$.

$+V a l u e s$ followed by the same letter are not significantly different $(P>.05)$. cumbers and other fast-growing vegetables would generally require a shorter weed-free period to establish dominance than would a slower-growing crop like bell peppers.

Herbicide treatments effectively increased cucumber yields over those in untreated plots (table 2). The combination of Alanap and Prefar, whether at standard application rates or at half-rate, was equivalent to keeping plots weed free for 2 weeks or 1 week, respectively (fig. 1, table 2). When half-rate herbicide applications were combined with a single hand hoeing 3 weeks after cucumber emergence, crop yields were equivalent to the best hand hoeing treatment In one study in which we combined half-rate herbicide treatments with hand hoeing either 3 or 5 weeks after cucumber emergence, the later hand hoeing was less effective at improving yields. At 3 weeks, cucumber vines and weeds were small enough so the weeds could be removed without excessive disturbance to the crop. At 5 weeks, cucumber vines trailed into the furrows and weeds were large; removing the weeds resulted in significant disturbance and damage to crop roots and vines.

Head lettuce. Spring and fall lettuce yields responded similarly to weed competition, so we combined the data from the two periods for analysis. Lettuce yields were not reduced significantly except where weeds were allowed to compete for the entire season (fig. 1). The rosette growth habit of lettuce allowed each plant to establish quick dominance of a small space around it. Weeds emerging after a singlehand hoeing ( 2 weeks after crop emergence) had little effect, since they were several inches away from the lettuce plants, and the short growth period of lettuce (11 to 12 weeks from planting to harvest) was not long enough to allow for much competition.

Unlike cucumber yields, lettuce yields did not decline with late-season hand hoeing, probably because the weeds could not germinate and grow very close to the lettuce plant. The weeds we removed were a short distance from the plants, so removal caused little disturbance. Weed species may also influence this observation, since the weeds used for the lettuce trials did not have the large, fibrous root systems of the weeds used in the cucumber trials.

Kerb applied at full or half-rate allowed yields equivalent to those in plots that were hand hoed once at 2 weeks postemergence (table 3). Reducing the rate of Kerb to $1 \mathrm{lb}$ ai/ acdid, however, substantially reduce control of shepherdspurse. Hand hoeing at 4 or 6 weeks did not increase yields over those treated with the herbicidealone (table 3 ). An observation was made, however, that hand hoeing at 6 weeks reduced the re-invasion of weeds, particularly shepherdspurse, and reduced insect damage to the lettuce.

Cauliflower. Weed competition did not affect cauliflower yields in this study (fig. 1). 
Once cauliflower emerged, its growth was rapid in both trials. The only weed species able to achieve greater height growth was London rocket. After hand hoeing 4 weeks after emergence, few weeds emerged, probably because of the dense canopy development of cauliflower.

Using the normal herbicide rate for cauliflower $(10 \mathrm{lb} \mathrm{ai} / \mathrm{ac})$ or reducing it to 6 or 4 $\mathrm{lb}$ ai/ac did not influence yields relative to weed-free conditions (table 4). Four or six pounds per acre of Dacthal provided temporary control of the weeds used in this study, enough time for the cauliflower to emerge and gain a height advantage. We performed no hand hoeing in combination with herbicides, since weed populations were not significant when Dacthal was used. Lower herbicide rates seem practical for this crop under these field conditions. High populations of London rocket, however, could interfere with harvest and necessitate hand hoeing.

Winter weeds used in both cauliflower and lettuce trials grew more slowly than the summer weeds used in the other vegetable trials. Although weed cover values in untreated plots were similar for the four crops studied, weed density and biomass were lower in the lettuce and cauliflower trial controls. Once weeds were removed by hand hoeing in these crops, invasion by new weeds was sparse.

\section{Conclusions}

The weed-free period necessary to achieve full crop yield depends upon the vegetable crop, the weed species, and the weed density. Cucumber, by virtue of its rapid growth and vining habit, was able to compete successfully againsthigh weed populations with as few as 2 or 3 weeks' weed-free maintenance. Bell pepper, a slower-growing vegetable crop, required a much longer weedfree period than cucumber to reach its full yield potential. Lower weed populations in the lettuce and cauliflower crops meant that yields were not reduced if the crops were weed-free for at least 2 weeks after emergence.

Hand hoeing appeared to harm crop yields once the crop or weeds had grown to a large size, so late-season hand hoeing should be avoided. Cucumbers, lettuce, and cauliflower were able to achieve full yield potential with 2 weed-free weeks after crop emergence. For these crops in combination with the weed species examined in this study, reducing the standard herbicide treatment by half can be combined with timely hand hoeing to equal or better the crop yields resulting from the standard herbicide treatment alone.

W. Thomas Lanini is Cooperative Extension Weed Ecologist, UC Davis; and Michelle Le Strange is Cooperative Extension Farm Advisor, Tulare and Kings counties.

\title{
Irrigation uniformity and cotton yields in the San Joaquin Valley
}

\author{
Dennis Wichelns $\square \quad$ J.D. Oster
}

Cotton yield data collected from 32 fields in the Broadview Water District are negatively correlated with several measures of soil salinity, sodicity, and irrigation uniformity. Results suggest that farmers may be able to increase cotton yields by improving irrigation uniformity on surface-irrigated fields.

Since 1979, when federal and state agencies began seeking long-term solutions to agricultural drainwater problems in the San Joaquin Valley, many experts have been suggesting that improvements to irrigation. management that would reduce drainwater volumes be made at the farm level. One proposal is to improve irrigation infiltration uniformity within farm fields. Non-uniform infiltration increases drainwater and may reducecropyields. More uniforminfiltration, on the other hand, may reduce drainwater volumes while increasing crop yields.

The most common irrigation method in the San Joaquin Valley's drainage problem area is siphon-tube furrow irrigation with $1 / 2$-mile runs. Irrigators generally run set times of 12 or 24 hours to accommodate labor and water availability. They can improve infiltration uniformity in furrow irrigation in a number of ways: reducing the length of furrow runs; increasing water inflow rates, and so reducing set times; using surge irrigation techniques, especially during pre-irrigations; or scheduling water deliveries and irrigations accurately to keep applied water depths in balance with evapotranspiration losses and soil water holding capacity.

Variations in soil characteristics constrain the degree to which irrigators can reduce drainwater volumes through improved water management. Soil characteristics govern the infiltration rates and uniformity of a surface-irrigated field. A properly designed and maintained pressurized irrigation system transfers most of the infiltration control to the system. Sprinkler irrigation, low-energy precision application (LEPA), and subsurface drip systems may improve infiltration uniformity in a field with considerable variation in soil characteristics.

Farm-leveldecisions regarding irrigation system improvements must take into ac- count the costs and returns involved in installing a new irrigation system or managing an existing system more efficiently. The annualized capital costs of siphon-tube and gated pipe systems range from $\$ 20$ to $\$ 30$ per acre, while those costs for pressurized sprinkler and drip irrigation systems range from $\$ 40$ to $\$ 180$ per acre. Reduced production costs (associated with labor, weed control, and tillage) offset some of the higher capital costs of a pressurized system, but the pressurized system's total annual costs remain the higher of the two, according to the 1988 report of the UC Committee of Consultants on Drainage Water Reduction, $A s-$ sociated Costs of Drainage Water Reduction.

Farmers need to see that there are economic advantages to pressurized irrigation if they are to switch over. The water savings from more efficient water application and the associated potential increases in yield are sources of increased net revenue. A lower drainwater volume will mean a major cost reduction for farmers who have to dispose of drainwater on their own property. The profitability of a furrow irrigation system for cotton falls below that of a subsurface drip, LEPA, or linear-movesprinkler system when thecost of drainwaterdisposal exceeds about $\$ 70$ per acre-foot, assuming the pressurized system applies water with greater uniformity. Once farmers seefield-level data that describe the potential benefits of improved irrigation uniformity, they will be more likely to implement irrigation management improvements and adopt pressurized systems where appropriate.

\section{Methods}

We collected data describing the soil characteristics, crop yields, and irrigation depths of 32 cotton fields $(3,682$ acres total) in the Broadview Water District during summer, 1987. Soil salinity and sodicity data came from the soil samples we collected, while irrigation and crop yield data came from district water delivery records and annual crop reports.

One soil sample was collected from the 0 to-3-foot depth interval at each of 20 sites arrayed in a rectangular grid in each field. Most fields encompassed 160 acres. Each sample was mixed thoroughly before subsampling. We prepared 8 samples for analysis of sodium adsorption ratio and the electrical conductivity of the saturated extract. 